\title{
Avipoxviruses: infection biology and their use as vaccine vectors
}

\author{
Simon C Weli ${ }^{*}$, Morten Tryland ${ }^{2,3}$
}

\begin{abstract}
Avipoxviruses (APVs) belong to the Chordopoxvirinae subfamily of the Poxviridae family. APVs are distributed worldwide and cause disease in domestic, pet and wild birds of many species. APVs are transmitted by aerosols and biting insects, particularly mosquitoes and arthropods and are usually named after the bird species from which they were originally isolated. The virus species Fowlpox virus (FWPV) causes disease in poultry and associated mortality is usually low, but in flocks under stress (other diseases, high production) mortality can reach up to 50\%. APVs are also major players in viral vaccine vector development for diseases in human and veterinary medicine. Abortive infection in mammalian cells (no production of progeny viruses) and their ability to accommodate multiple gene inserts are some of the characteristics that make APVs promising vaccine vectors. Although abortive infection in mammalian cells conceivably represents a major vaccine bio-safety advantage, molecular mechanisms restricting APVs to certain hosts are not yet fully understood. This review summarizes the current knowledge relating to APVs, including classification, morphogenesis, host-virus interactions, diagnostics and disease, and also highlights the use of APVs as recombinant vaccine vectors.
\end{abstract}

\section{Introduction}

Avipoxviruses (APVs) are among the largest and most complex viruses known. APVs belong to the Chordopoxvirinae subfamily of the Poxviridae family [1]. They infect and cause diseases in poultry, pet and wild birds of many species which result in economic losses to the poultry industry. Infections have also been reported in a number of endangered species or species in captivebreeding recovery programs [2-4]. APVs are transmitted via biting insects and aerosols and are usually named on the basis of the bird species from which the virus was first isolated and characterized [4]. The disease, which is characterized by proliferative lesions of the skin and diphtheric membranes of the respiratory tract, mouth and oesophagus has been described in avian species $[4,5]$. Although APV infections have been reported to affect over 232 species in 23 orders of birds [6], our knowledge of the molecular and biological characteristics of APV is largely restricted to fowlpox virus (FWPV) and canarypox virus (CNPV) for which fullgenome sequences are available $[7,8]$. Currently, only ten avipoxvirus species are listed under the genus by the

\footnotetext{
* Correspondence: simonweli@hotmail.com

${ }^{1}$ National Veterinary Institute, Ullevålsveien 68, N-0106 Oslo, Norway

Full list of author information is available at the end of the article
}

International Committee on Taxonomy of Viruses (ICTV) [1]; Table 1. Thus, it is safe to assume that many APVs have yet to be characterized. Recombinant APVs have been evaluated for use as vaccine vector candidates against infectious diseases [7,9]. APV-vectored vaccines are already in use in veterinary medicine [10-14], and it is likely that such vaccines will also be used against human diseases in the future. This fact emphasizes the need to learn more about the molecular characteristics of APVs, which underpins the development of safe APV-vectored recombinant vaccines. This review summarizes current knowledge of APVs as avian pathogens, including classification, morphogenesis, hostvirus interactions, diagnosis, as well as issues relevant to their use as recombinant vaccine vectors.

\section{Definition}

Avipoxviruses are large, oval-shaped enveloped viruses whose genome consists of double stranded DNA ranging in size from 260 to $365 \mathrm{~kb}$ [8]. Unlike most other DNA viruses, APVs replicate easily in the cytoplasm of infected avian cells which results in a characteristic cytopathic effect (CPE) 4 to 6 days post infection depending on the virus isolate [4]. APVs also multiply on the chorioallantoic membrane (CAM) of embryonated eggs, resulting in
C Biomed Central

(c) 2011 Weli and Tryland; licensee BioMed Central Ltd. This is an Open Access article distributed under the terms of the Creative Commons Attribution License (http://creativecommons.org/licenses/by/2.0), which permits unrestricted use, distribution, and reproduction in any medium, provided the original work is properly cited. 
Table 1 Members of the genus Avipoxvirus and their host spectrum

\begin{tabular}{|c|c|c|c|c|c|}
\hline Type species & Hosts & Latin names & Mode of infection & Disease confirmation & References \\
\hline Fowlpox virus ${ }^{1 a}$ & Chicken & Gallus gallus & $E, N$ & HP, CAM, EM, PCR/Seq & {$[7,21,27,113]$} \\
\hline Canarypox virus ${ }^{1 \mathrm{~b}}$ & Canary (several species) & Serinus canarius & $\mathrm{E}, \mathrm{N}$ & HP, CAM, EM, PCR/Seq & {$[8,17,114,115]$} \\
\hline Juncopox virus $^{1}$ & Slate coloured Junco & Junco hyemalis & E & GE & {$[48]$} \\
\hline Mynahpox virus ${ }^{1}$ & Greater hill mynahs & Gracula religiosa & $\mathrm{E}, \mathrm{N}$ & $\mathrm{HP}$ & [116] \\
\hline Psittacinepox virus ${ }^{1}$ & Parrot & Amazona finschi & & HP,CAM & {$[62]$} \\
\hline Quailpox virus $^{1}$ & Scaled quail & Callipepla squamata & $\mathrm{N}$ & HP, CAM, EM & {$[117]$} \\
\hline Sparrowpox virus $^{1}$ & Sparrows & Passer domesticus & $N$ & HP, CAM, EM, PCR/Seq & {$[16,18]$} \\
\hline Starlingpox virus $^{1}$ & Regal starling & Cosmopsarus regius & $N$ & HP, CAM, EM & [118] \\
\hline Turkeypox virus ${ }^{1}$ & Turkey & Meleagris gallopavo & $N$ & $H P, C A M, E M, P C R$ & [119] \\
\hline Crowpox virus $^{2}$ & Hawaiian crows & Corvus hawaiiensis & $N$ & $\mathrm{HP}, \mathrm{CAM}$ & {$[4]$} \\
\hline Peacockpox virus ${ }^{2}$ & Peacock & Pavo cristatus & $\mathrm{N}$ & HP, CAM & [120] \\
\hline Penguinpox virus ${ }^{2}$ & Penguin & Spheniscus demersus & $N$ & CAM & [59] \\
\hline Pigeonpox virus & Pigeon & Palumbus palumbus & $N$ & HP, CAM, EM, PCR/Seq & {$[16,18]$} \\
\hline Flamingopox virus & Flamingo & Phoenicopterus roseus & $N$ & $\mathrm{PCR} / \mathrm{Seq}$ & {$[121]$} \\
\hline Partridgepox virus & Partridges & Perdix perdix & $N$ & $\mathrm{HP}, \mathrm{EM}, \mathrm{PCR} / \mathrm{Seq}$ & [122] \\
\hline Sea Eaglepox virus & Sea eagle & Haliaeetus albicilla & $N$ & $\mathrm{HP}, \mathrm{PCR} / \mathrm{Seq}$ & [123] \\
\hline Great titpox virus & Great tit & Parus major & $\mathrm{N}$ & $\mathrm{HP}, \mathrm{EM}, \mathrm{PCR} / \mathrm{Seq}$ & {$[18,124]$} \\
\hline Curlewpox virus & Curlew & Burhinus oedicnemus & $N$ & HP, EM, PCR/Seq & {$[125]$} \\
\hline Common buzzardpox virus & Common buzzard & Buteo buteo & $N$ & HP, CAM, EM, PCR/Seq & [126] \\
\hline American crowpox virus & American crow & Corvus brachyrhynchos & $N$ & $\mathrm{HP}$ & {$[127]$} \\
\hline Ostrichpox virus & Ostrich & Struthio camelus & $N$ & $\mathrm{HP}, \mathrm{CAM}$ & {$[128,129]$} \\
\hline Owlpox virus & Owl & Strix varia & $N$ & HP, CAM & [130] \\
\hline Goosepox virus & Canada Goose & Branta canadensis & $N$ & $\mathrm{HP}, \mathrm{CAM}$ & {$[15]$} \\
\hline Magpiepox virus & Magpie & Pica pica & $N$ & HP, CAM, EM & {$[16]$} \\
\hline Mockingbirdpox virus & Mockingbird & Mimus polyglottus & $N$ & $\mathrm{HP}, \mathrm{EM}$ & [131] \\
\hline
\end{tabular}

Mode of infection: N, natural; E, experimental; HP, histopathological; CAM, chorioallantoic membrane; EM, electron microscopy; PCR, polymerase chain reaction; Seq, sequencing and GE, genetic and antigenic characterization.

${ }^{1}$ Currently classified by ICTV as members that belong to genus Avipoxvirus.

${ }^{2}$ Currently classified by ICTVas tentative members of genus Avipoxvirus.

${ }^{a}$ Complete genome sequences exists: Fowlpox virus FP9 (plaque-purified tissue culture-adapted attenuated European virus; accession number: AJ581527) and Fowlpox challenge virus (Animal Health Inspection Service Centre for Veterinary Biologicals, Ames lowa; accession number: AF198100).

${ }^{b}$ Complete genome sequence exists: Canarypox virus strain Wheatley (American Type Culture Collection; ATCC VR-111).

the formation of compact, proliferative pock lesions that are sometimes focal or diffuse [15]. However, some isolates, especially from the host species great tit (Parus major), have failed to multiply on CAM of chicken embryos [16]. APVs are the etiologic agent of disease characterized by skin lesions in both wild and domestic birds $[4,5]$. Histologically and ultrastructurally, APVs undergo morphologic stages that are similar to other chordopoxviruses, including the formation of intracytoplasmic inclusions bodies, a characteristic which has been observed in some epithelial and mononuclear cells of permissive hosts. APV particles can be detected and further characterized by use of transmission electron microscopy (TEM) $[17,18]$.

\section{Classification}

Great discoveries made in the mid-nineteenth century facilitated major advances in pox virology. Based on the report by Bollinger [5] on poxvirus infected cells in chickens, and subsequent work by Fenner and Burnet [19], APVs and other poxviruses were classified on the basis of original host, growth and morphological characteristics in the CAM of embryonated eggs or cell cultures and on clinical manifestations in different diseases of humans, birds and animals [20] rather than on genetic identity, which may provide both rapid and reliable virus identification [21-23]. These criteria have remained the basis for subsequent classification of APVs despite development of new molecular tools that have the capability of resolving the issue of species specificity of APV.

Members of the genus Avipoxvirus belong to the subfamily Chordopoxvirinae which shares several biological features with other poxviruses $[7,8]$. Currently, little is known of the number of species within the genus. While only ten strains have so far been identified and classified Worldwide as APV [1], avian poxvirus infections have been reported to affect a wide range of bird 
species [6]. These strains vary in virulence and host specificity, demonstrating an urgent need for further analyses and characterization of new isolates.

\section{Structure}

Avipoxviruses share several morphological, biochemical and physiochemical features with other poxviruses. Virus particles measure $270 \times 350 \mathrm{~nm}$ and are composed of an electron dense, centrally located core and two lateral bodies that are visible in fixed and stained ultra-thin sections. In negative stained preparations, such as phosphotungstic acid (PTA) the membrane displays an outer-coat composed of a random arrangement of tubules [24]; Figure 1. APV particles have been shown to be resistant to ether, but sensitive to chloroform treatment [25], although resistance to both chloroform and ether have been reported for pigeonpox virus and two pigeonpox virus mutants [26].

\section{Genome}

Avipoxviruses have low $\mathrm{G}+\mathrm{C}$ content (30 to $40 \%$ ) and consist of a single linear molecule of double-stranded DNA of between 260-365 kb. The central region of the genome is flanked by two identical inverted terminal repeats (ITRs) which are covalently linked by hairpin loops and contains several hundred closely spaced open reading frames [7]. The central region contains about 90-106 homologous genes that are involve in basic replication mechanisms, including viral transcription and RNA modification, viral DNA replication, and proteins

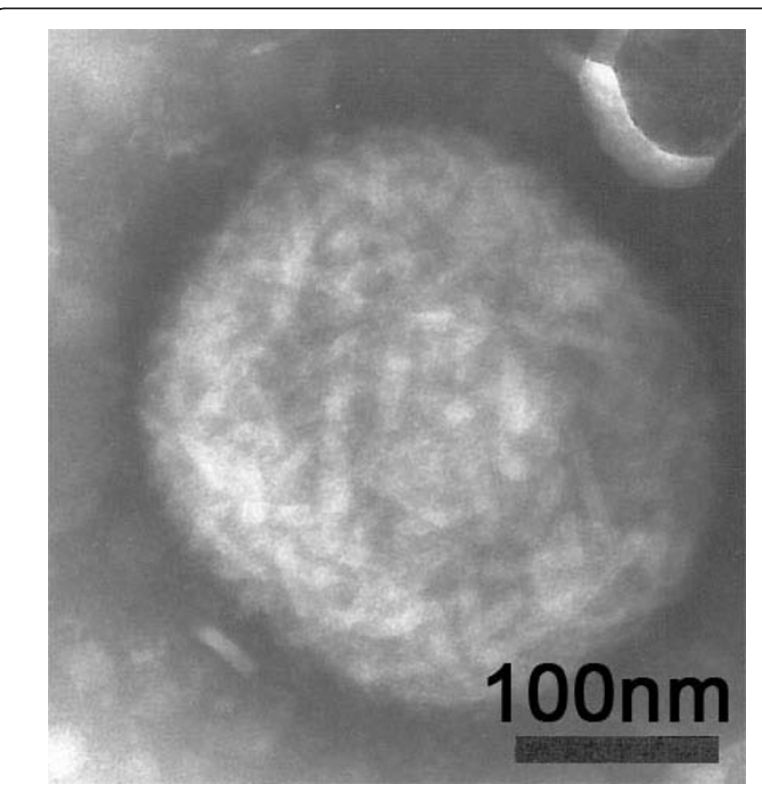

Figure 1 Negative stain EM of a characteristic FWPV-particle propagated in baby hamster kidney (BHK) cells at 72 hour post infection. involved in structure and assembly of intracellular mature virions and extracellular enveloped virions [8]. In general, genes located in this region have common molecular functions and are relatively conserved among poxviruses [8]. This is in contrast to the more variable, terminally located genes that have been shown to encode a diverse array of proteins involved in host range restriction [8].

Complete genomes of the two most studied APVs, FWPV US (FP-challenge virus; Animal Health Inspection Service Centre for Veterinary Biologicals, Ames Iowa, USA), FWPV-FP9 (a plaque-purified tissue cultureadapted attenuated European virus) and a CNPV virulent strain (Wheatley C93, American Type Culture Collection; ATCC VR-111) have been sequenced [7,8,27]. Although nucleotide and amino acids sequences for these two viruses are known, the functions of some putative genes and proteins remain to be fully assigned. Comparison of the FP9 strain with FWPV US revealed 118 differences; of which 71 genes were affected by deletion (26 of 1-9334 bp), insertion (15 of 1-108 bp), substitution, termination or frame-shift [27]. FP9 strain is a derivative of European FWPV HP1 which was obtained through over 400 passages in chicken embryo fibroblast (CEF). Analysis of FWPV HP1 sequences at the loci in which differences exist between FP9 and FWPV US show that 68 of 118 loci differ from the FWPV US, but were identical to FP9. This thus indicate that more than half of the differences between the two geographic FWPV lineages represented differences between the parent virulent viruses FWPV HP1 and FWPV US [27]. Further comparison of molecular data; show that FWPV and CNPV share high aminoacid identity, significant gene-sequence rearrangements, deletions and insertions [8]. The CNPV genome is about 80-100 kbp larger than the FWPV genomes. Both FWPV and CNPV express cellular gene homologues with immunomodulatory functions, which might be responsible for their different virulence and host-range [8], but CNPV shows a broader tissue tropism in permissive avian hosts [17] than FWPV. CNPV has additional sequence of over $75 \mathrm{kbp}, 39$ genes lacking in FWPV homologues and approximately $47 \%$ amino-acid divergence [8]. These divergences are primarily found in the terminal nonconserved regions $[7,8]$. Genes located in the non conserved regions are more prone to mutation and recombination and are implicated in host range, immunomodulation and pathogenesis [28], and may be responsible in some aspects of cell and/or tissue tropism or perform other cellular functions [8].

Virulence genes are generally of non-conserved nature and influence the pathological profile of viruses in an infected host. These genes are important in viral evolution and have been used in studies to provide insight into how some poxviruses evolve strategies to ensure 
their replication [29]. Many of these strategies can be traced back to discoveries made with knockout (KO) viruses, in which a targeted disruption of a specific viral gene produced phenotypic changes reflective of the normal biological function of its protein product. Deletions of some non-conserved genes have also resulted in conditional replication defects in specific cell types [30], such as the demonstration of spontaneous deletion of host range genes of vaccinia virus resulting in the compromised growth in the mammalian cell [31]. The K1L and $\mathrm{C7L}$ genes of vaccinia virus have been shown to be essential for completion of the replication cycle of vaccinia virus in human cells [32,33]. In a knockout experiment, vaccina virus was unable to complete its replication cycle in Chinese hamster ovary $(\mathrm{CHO})$ cells, since replication was aborted shortly after virus binding and entry, at the stage of intermediate gene expression [34]. But the insertion of another host range gene, $\mathrm{CHOhr}$ from cowpox virus into vaccinia virus allowed vaccinia virus to grow in $\mathrm{CHO}$ cells in which they are normally restricted [35-37]. Through use of these techniques, we now have a better understanding of the biology of vaccinia and other poxviruses, including their host range restriction. Although, some major advances have been made in genome sequencing and in vitro characterization of APVs $[7,8,38,39]$, studies on APV host range genes are scarce. A wide array of gene homologues with likely host range functions such as NK-cell receptors, chemokines, serine protease inhibitors and homologues of genes involved in apoptosis, cell growth, tissue tropism and avian host range, have been identified in APVs, which suggests significant viral adaptation in the avian host [7]. Molecular knockout studies that target identification and further characterization of viral genes involved in regulation of cell proliferation, chromatin remodelling, virulence and apoptosis, in different APV-infected mammalian and avian cells are needed to better understand the tissue tropism and host range characteristics of APVs, including the abortive infection in mammalian cells.

\section{Host-virus interaction}

Compared to other poxviruses, such as vaccinia virus, mechanisms that account for APV pathogenesis is poorly understood. APVs have evolved a variety of elegant mechanisms to deliver their genes and accessory proteins into host cells. Like many other DNA viruses, APV probably devotes much of its genes to allow it to evade host immune responses. Such viral genes commonly encode proteins that are critical for the virus to undergo molecular transformation that leads to successful membrane fusion, penetration and intracellular transport. These includes genes that encodes proteins which act on early innate pathways such as pathways involving interferon [40], pattern recognition receptors as Toll-like receptor (TLR) [41], chemokines [42] and cytokines [43], as well as pathways that act on subsequent adaptive responses [44,45]. The infection of a cell by a virus is a complex process, during which the virus must overcome several host factors restriction points and the host immune response. Host protein interaction networks and biochemical pathways are in most cases altered by the viral proteins that free the virus from normal cellular controls and allow nucleotide metabolism in cells that have shut down DNA synthesis [46]. Hence, understanding viral protein functions and their interactions with host proteins is a prerequisite, not only to understand the infection biology of the virus-host system in question, but also for the rational development of target vaccines, based on specific antigens and possibly immunomodulatory factors, as well as antiviral compounds.

\section{Replication}

Since the first isolation of APVs in cell culture, these viruses have been recognized as highly host specific. They are believed to replicate only in avian cells, notably chicken embryo fibroblasts (CEF; American Type Culture Collection; ATCC, Rockville, Maryland, USA; CRL1590) [47]. CEF cells have a good split ratio compared to other cell lines, and are thus useful for large-scale propagation of virus, such as antigen production for vaccines or as a diagnostic tool. APVs have also been shown to replicate in chicken embryo kidney, chicken embryo dermis $[48,49]$ and quail cell lines, such as QT35 , although the presence of viable endogenous herpesvirus and Marek's disease virus (MDV) in QT-35 cells, limits their use for preparation of vaccines $[4,50]$. APV have been isolated once from a mammal. In 1969, viable FWPV was isolated from a terminally ill rhinoceros [51]. The isolate was identified as atypical FWPV, based on pathological, virological and serological characteristics [51]. Nelson (1941) [52] reported mild pathology in mice following intranasal inoculation with FWPV, with no virus replication. Recent studies have also shown replication of APV in mammalian cell cultures, such as embryonic bovine tracheal cells [53] and baby hamster kidney cells [54] that are defined by the presence of infectious viral particles and CPE. These studies raise questions about the species specificity and mechanisms that restrict these viruses to certain hosts, and challenge the hypothesis that APV cannot undergo a full replication cycle in mammalian cells.

\section{Morphogenesis}

The cellular entry and exit of APV is complicated by the existence of at least two distinct forms of virus that can productively infect cells, namely the intracellular mature 
virus (IMV) and the extracellular enveloped virus (EEV). These two forms are surrounded by different lipid membranes and surface proteins that are yet to be fully characterized.

After virus binding to cellular membranes, a fusion step, which is generally poorly understood, results in the release of the virion core into the cytoplasm of the cell [39]. The released core, which contains the endogenous RNA polymerase and transcription factors, initiates the first wave of early viral gene transcription by synthesizing viral mRNA under the control of early viral promoters. This is followed by the uncoating stage, the release of viral DNA into the cytoplasm where it serves as a precursor for viral DNA replication as well as the source of intermediate and late viral gene transcription. As a late viral gene product accumulates, the virus undergoes assembly and morphogenesis of infectious virus particles. During morphogenesis, APVs induce the formation of inclusion bodies in the cytoplasm of infected cells (Figure 2A and 2B). The inclusions, which may also be termed viral factories, viroplasms, or viral replication complexes, are generally believed to be the sites of active viral replication and particle assembly within infected cells [17]. One model for the function of viral inclusion bodies is that they act to concentrate and sequester proteins, nucleic acids, and other small molecules essential for viral processes.

In permissive cells, the first viral structures detectable by electron microscopy are the crescent-shaped forms (Figure 3A), consisting of a membrane with spicules on the convex surface [39]. These structures develop into non-infectious spherical immature viruses
(IV) (Figure 3B) from which the intracellular mature virus (IMV) is formed by a series of maturation steps (Figure 3C). The IMV represents the majority of infectious progeny from each infected cell $[17,39,55]$. There are three possible mechanisms by which poxviruses are released from host cells depending on the strain of virus, cell type and the post-infection time [54-56]. They can be released by cytolysis, in which case IMV are released when the cell undergoes lysis as a result of CPE at the advanced stage of infection. It can also be released via virus-induced exocytosis. The third way of release is by budding, in which case IMV migrates out of the virus factory through the plasma membrane. Budding is shown to be the main exit route for APV [39] in contrast to the orthopoxviruses which exit by exocytosis of intracellular enveloped virus (IEV) [57]. These exit processes all result in the acquisition of an additional double membrane $[39,55]$. In non-permissive African green monkey cells (CV-1, Vero) and in a human cell line (MRC-5), there is a blockade of the APV morphogenesis cycle. This occurs in steps following the formation of immature virus and is shown to be devoid of an alteration in early gene expression $[47,58,59]$, indicating that this blockade may not be associated with cell receptors.

Poxvirus tropism may not be dependent upon specific cell surface receptors, but rather upon the ability of a given cell to provide intracellular complementing factors needed for productive virus replication, and on the ability of the specific virus to successfully manipulate intracellular signaling networks that regulate cellular antiviral processes following virus entry [28]. APVs have large
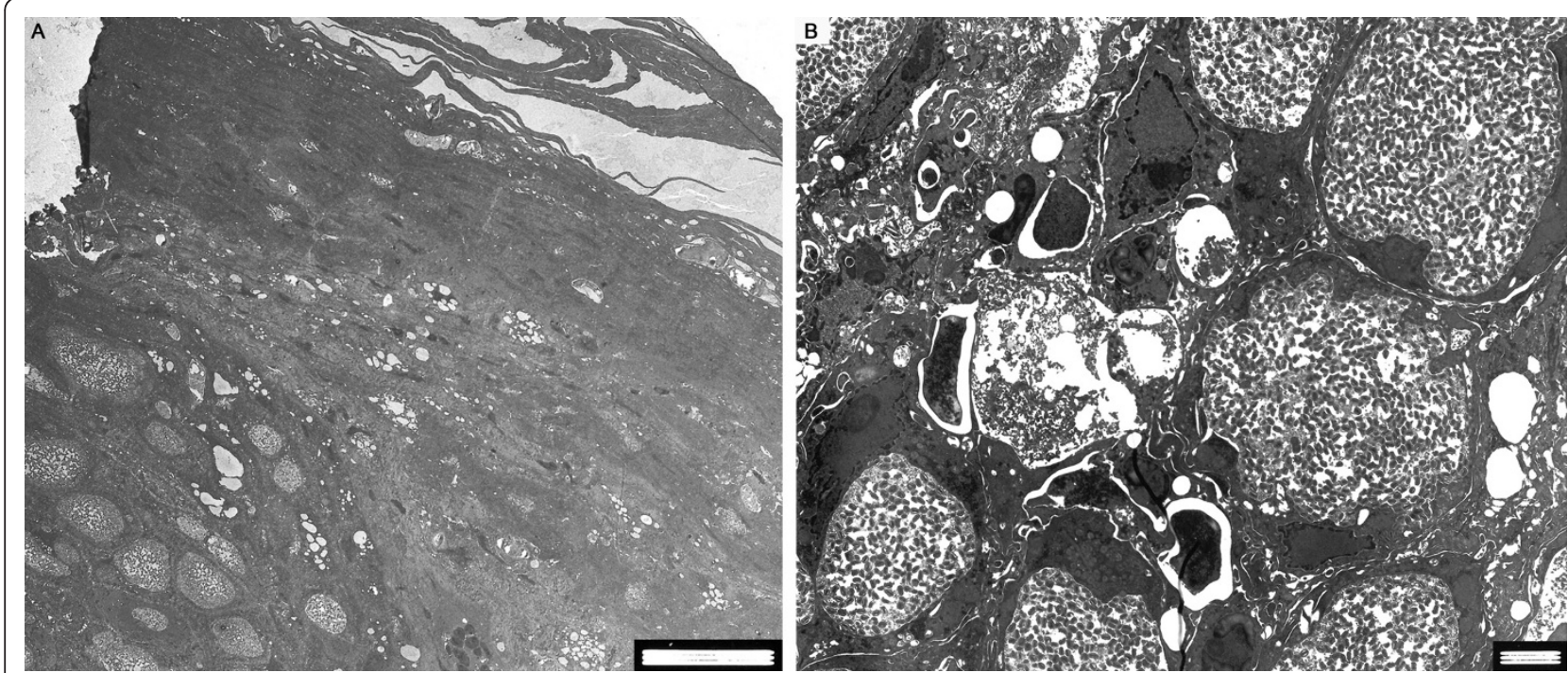

Figure 2 A and B Transmission electron microscopy (TEM) of FWPV-infected (A) bird skin tissue showing outer layers of epidermis, with typical inclusion bodies (Bollinger bodies) in the dermis (bar $=20 \mu \mathrm{m}$ ) and (B) cells with characteristic intracytoplasmic inclusion bodies containing viral particles (bar $=2 \mu \mathrm{m}$ ) 

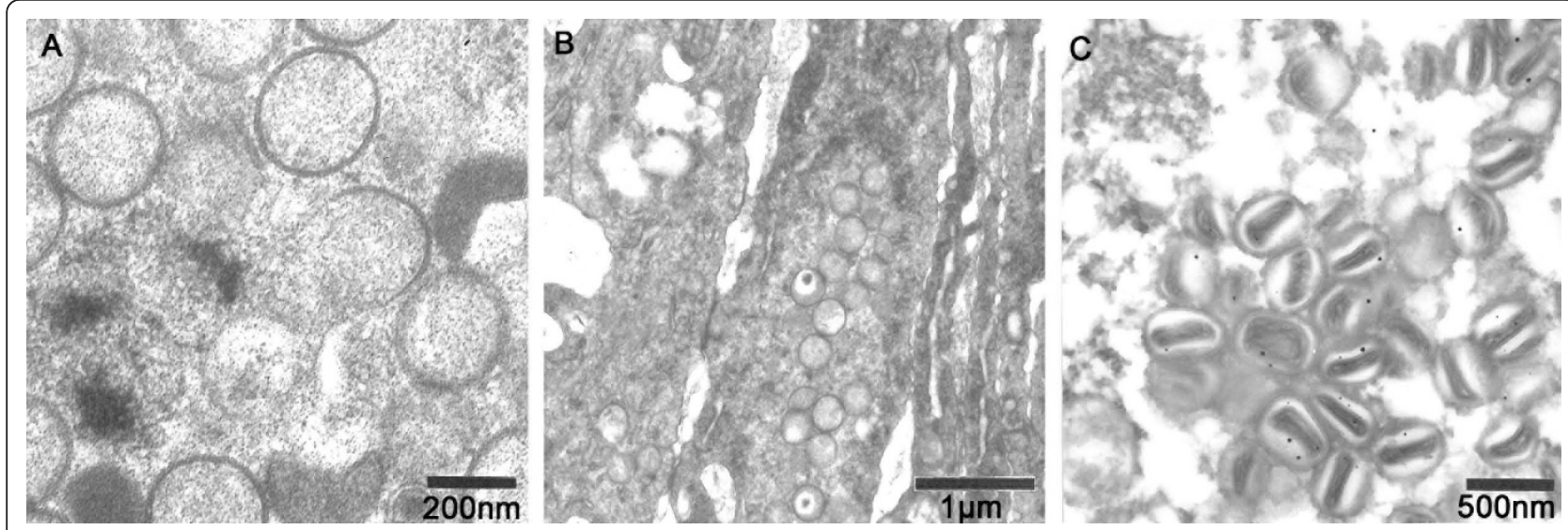

Figure 3 A, B and C Virion morphology of avipoxviruses in chicken embryo fibroblast cells (CEF). (A) Electron microscopy showing crescent-shaped structures consisting of a membrane with spicules on the convex surface, (B) spherical non-infectious immature viruses (IV) which give rise to formation of $(\mathrm{C})$ intracellular mature virions (IMV) by a series of maturation steps.

genomes that would enable them to express unique collections of viral proteins that function as host range factors, which specifically target and manipulate host signaling pathways to establish optimal cellular conditions for viral replication. However, in some cells, especially mammalian cells, APV replication is blocked. This may be due to the ability of APV to specifically activate signalling pathways or mediators, for example interferon pathways, in those cells. The role of mediators and immunopathology of APV is complex and not well understood. However, considering the numerous steps involved in APV morphogenesis, it is relevant to note that these viruses induce several mediators that allow them to survive and interact with the host cells. Some potential mediators have been identified [7] and are awaiting proper functional characterization. These molecules alone may not fully explain the events that have been documented in mammalian cells that have supported the replication of APV [54]. Hence, identification of new mediators that are up or down-regulated in response to APV infected mammalian and avian cells could help advance our knowledge of immune responses against APV and the related immune-mediated pathology and cell tropism. It would be of vital importance to investigate these characteristics further, especially for the cell types that were recently shown to support APV replication [53,54].

\section{Pathogenicity}

APV infections are associated with significant levels of morbidity and mortality in domestic and wild bird populations $[6,60]$. Most of the investigations and reported cases are based on single APV isolates, which makes it difficult to address the pathogenicity of different APVs in different bird species. Chickens are commonly used to determine the pathogenicity of new isolates, but chickens may not be the ideal host, since APVs from wild birds may not multiply in chickens. In an attempt to identify and characterize the pathogenicity of APVs, Tripathy and others [4] found that wild isolates of Hawaiian crowpox virus had a generally mild pathogenicity in domestic chickens, characterized by relatively minor lesions of short duration at the sites of inoculation, which were in contrast to the general ability of FWPV strains to produce extensive proliferative lesions [4]. In another experimental study, two APV isolates obtained from endangered Hawaiian wild birds, the Hawaiian Goose (Branta sandvicensis) and the Palila (Loxioides bailleui), were compared with FWPV in specific-pathogen-free chickens. Immune responses were measured by ELISA before and after immunization with Hawaiian APVs and after challenge with FWPV. Both isolates from Hawaiian birds developed only a localized lesion of short duration at the site of inoculation in chickens and did not provide protection against subsequent challenge with virulent FWPV, in which severe lesions were observed. In contrast to high antibody response in chickens immunized with FWPV, birds immunized with either of the two Hawaiian isolates developed low to moderate antibody responses against viral antigens [61]. Pathogenicity studies of APVs in parrots [62], turkeys, pigeons and canaries have also been reported. Canaries were highly susceptible to CNPV, but showed resistance to turkeypox virus, FWPV and pigeonpox virus $[4,63,64]$. A poxvirus from a Canada goose (Branta canadensis) was transmissible to domestic goose, but not to chickens or domestic ducks [15]. Pigeonpox virus produced mild infection in chickens and turkeys, but was more pathogenic for pigeons [62]. Poxvirus isolates from magpies (Pica pica) and great tits (Parus major) did not infect young 
chickens [16], however, poxvirus isolated from blackbacked magpie (Gymnorhina tibicen) produced lesions in chickens. These studies were based on clinical manifestations in the chickens and suggest host specificity and pathogenicity.

Despite the worldwide prevalence of APV infections, experimental infection studies in birds using APVs have centred on relatively few viral isolates. Analyses of variation have essentially focused on a FWPV strain termed the prototype, while a minority of experimental studies have been reported on CNPV, quailpox, juncopox, and pigeonpox virus isolates $[4,48,49]$. In fact, in the last twenty years, approximately $50 \%$ of published studies on APVs have been on the FWPV isolate directly (based on a PubMed search on APVs). The important nature of APVs which has been used successfully for vaccine development mandates that a larger pool of viral strains should be analyzed both for consideration of pathogenesis and determination of immune correlates of protection.

\section{Antigenic and genetic variability among APVs}

Our present understanding of the antigenic variation of APVs has been based on a limited number of virus isolates in assays that includes complement-fixation, passive hemagglutination, agar-gel precipitation, immunoperoxidase, virus neutralisation and immunofluorescence $[48,49,65]$. In addition to the immunological assays, variation of APVs has also been addressed through genetic assays, such as restriction enzyme analysis. Genomes of FWPV and quailpox virus isolates were compared by using BamHI, EcoRI, and HindIII endonucleases and distinct fragment patterns were observed between the isolates. The patterns of three quailpox virus isolates were similar to each other with a high proportion of comigrating fragments. However, when immunogenic proteins of three FWPVs, two quailpox viruses, a juncopox virus, and a pigeonpox virus isolates were examined by immunoblotting, shared as well as unique antigens were detected. The greatest disparity was observed between quailpox virus and FWPV $[48,49]$, indicating extensive variation between the quailpox virus and FWPV, which would predict differences in immunogenicity and antigenicity, including neutralization sensitivity. Nucleotide sequence based studies for rapid identification of poxvirus species by PCR with specific primers and hybridisation are well established [21]. These approaches have concentrated on single genes or portions of genes that exhibits variations in their sequence and are important for quick analysis of genetic variability [22].

\section{Phylogeny}

Understanding the phylogenetics of APVs is essential to the understanding of host specificity and virulence, but also to provide insights into the variation of different viruses. Although the complete genome sequences of FWPV and CNPV are available [7,8], little is known about APV phylogeny. This is probably because of the difficulty in identifying pan-genus or species-specific PCR primers that can be used to amplify different genes. The most common PCR locus used until now has been the P4b locus [21]. Recent phylogenetic studies of APV isolates based on this locus $[22,23]$ indicated that most isolates clustered around either CNPV or FWPV, while another study based on the same locus demonstrated a third cluster, from psittacine birds [66]. Amano and coworkers [38] showed that the CNPV thymidine kinase locus was highly diverged from that of FWPV. The extent of this divergence was further illustrated by the fact that the amino acid similarity between CNPV and FWPV orthologue P4b was only $64.2 \%$ [23,38]. A recent study, based on three different genes including the $\mathrm{P} 4 \mathrm{~b}$, revealed that penguinpox virus, isolated from lesions around the eyes of African penguins (Spheniscus demersus), was most closely related to turkeypox virus, ostrichpox virus and pigeonpox virus [67].

\section{Diseases}

During avipox outbreaks, mortality can reach 80 to $100 \%$ in canaries and other finches. This is in contrast to a generally lower mortality seen in chicken and turkey [60]. Transmission of virus can occur through a break in the skin or, more commonly, when vectored by biting insect such as mosquitoes and mites [68]. Aerosols generated from infected birds, or the ingestion of contaminated food or water have also been implicated as a source of transmission [69]. The disease is most commonly characterized by cutaneous proliferative lesions consisting of epithelial hyperplasia of the epidermis that resulting in proliferative, wart-like projections. They are primarily confined to unfeathered parts of the body, such as legs, feet, eyelids and the base of the beak (Figure 4). Scars are usually visible after recovery and healing of skin lesions. The mortality in wild birds is usually low, depending on the number and size of the proliferative lesions. However, if infection occurs in feather-free areas of the skin, with secondary bacterial infection, mortality may be high. The other and less common form of APV infections is the diphtheritic or wet form [70] which occurs as fibrino-necrotic and proliferative lesions in the mucosa of the digestive and upper-respiratory tracts, and generally has a higher mortality than the cutaneous form [60]. In some instances, birds display both cutaneous and diphtheritic forms and in those cases, mortality rates are often higher compared to the cutaneous form alone. Despite the variety of hosts and virus strains, associated pathology remains the same in infected domestic birds, although clinical signs vary depending on the virulence of the virus, susceptibility of 

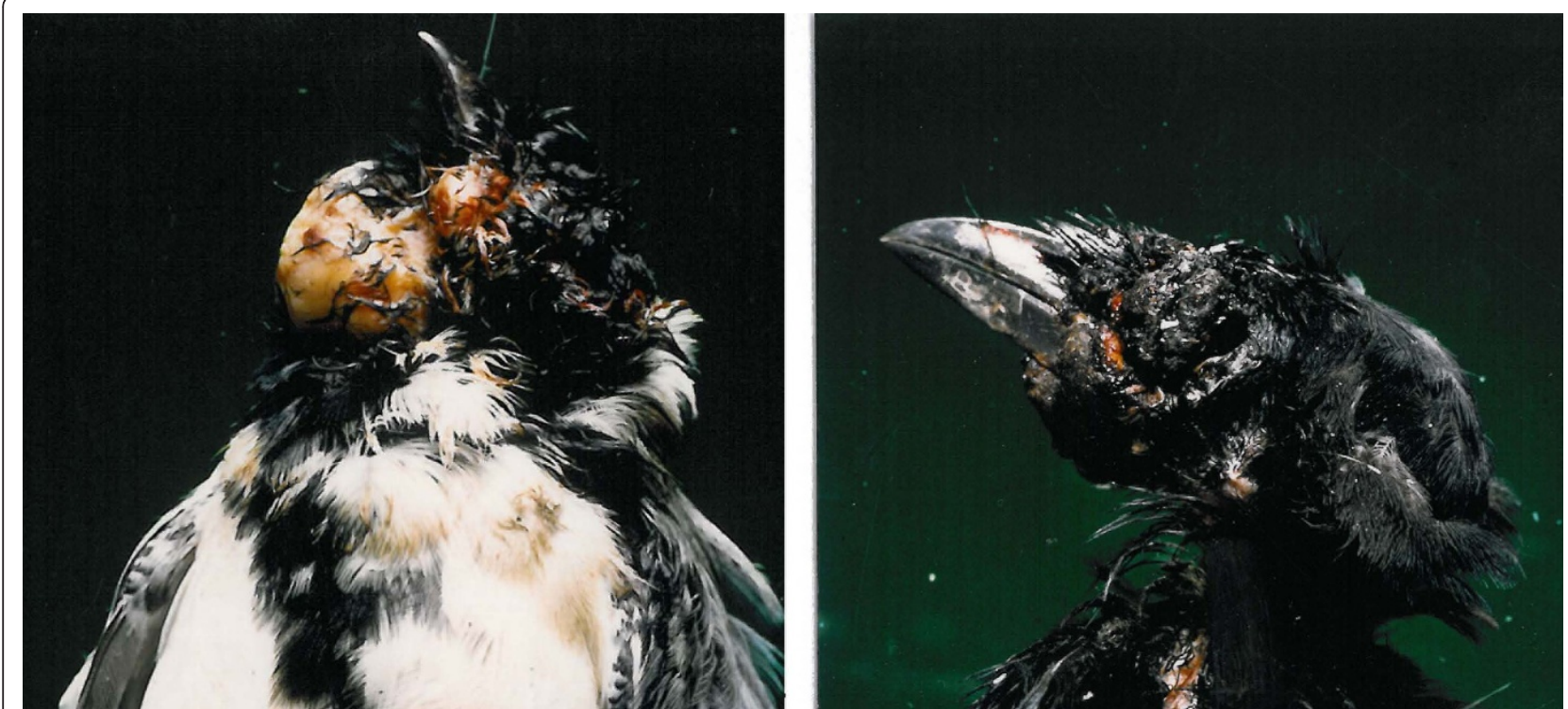

Figure 4 Avipoxvirus infection of a great tit (Parus major) (left) and a common magpie (Pica pica) (right). The protecting feather coat is destroyed. Proliferative lesions and crust are seen, with secondary bacterial infection (Photo: Gunnar Holt, National Veterinary Institute, Oslo, Norway).

the host, distribution and type of lesions [60]. There exist a relationship between FWPV and the avian retrovirus, reticuloendotheliosis virus (REV) (see section on APVs and REV). However, the possible roles that simultaneous REV infection arising from the provirus integration into the FWPV genome might play in the expression FWPV during disease outbreak remain unresolved. It is well known that REV infection leads to immunosuppresion [71] in affected birds. Thus, it is plausible to suggest that the presence of REV in FWPV infection may exacerbate disease progression. In spite of the fact that some mammalian cell lines seems to be able to support the replication of APVs, there is no evidence that APVs have caused clinical disease in humans, in contrast to what is known for other poxviruses, such as several parapox and orthopoxviruses.

\section{Diagnosis of APV infections Clinical diagnosis}

Clinical features of infected birds show multiple skin lesions varying from papules to nodules. Gross lesions in both the cutaneous and the diphtheritic forms, seen on birds and during necropsy, are usually sufficient to suspect APV infection [60]. However, these signs are sometimes not sufficient for definitive diagnoses of APV infection as other agents, such as papilloma virus, scaly leg mites [72] and mycotoxins may produce similar lesions in the skin [60], and conditions like candidiasis, capillariasis and trichomoniasis may give lesions in the oral cavity similar to the diphtheritic form of APV infection [73]. It is therefore crucial to secure samples and confirm the viral etiology of the condition.

\section{Laboratory diagnosis}

\section{Histopathology and electron microscopy}

Suspicion of clinical signs of APV infection can if possible be supported by necropsy, especially if the oral cavities to reveal the diphtheritic form. Further, histopathology on tissue sections using the classic Wright's Giemsa stain may reveal typical large, solid or ring-like, eosinophilic intracytoplasmic inclusions known as Bollinger bodies [5]; Figure $2 \mathrm{~A}$ and $2 \mathrm{~B}$. Transmission electron microscopy (TEM) may also reveal definite proof of APV infection, demonstrating the typical APV particles within inclusion bodies. APV identification may also be carried out by negative staining electron microscopy with $2 \%$ phosphotungstic acid (PTA) on infected cells (Figure 1). This method has typically been used by national reference or research laboratories to identify APV [18].

\section{Virus isolation}

Demonstration of infectious virus by inoculation of homogenates of clinical samples of typical APV skin lesions onto the CAM of embryonated hen's eggs is the gold standard method for diagnosis of APV, although some strains of APV do not grow readily on chicken embryos [16]. Eggs are first swabbed with 70\% alcohol and a pore is made in an area over the air-cell and another one on the other side of the egg to make a false air sac and lower the CAM by negative pressure using a rubber bulb. Inoculation of infectious samples by the 
CAM route is performed with sterile disposable $1 \mathrm{~mL}$ syringe with approximately $0.1-0.2 \mathrm{~mL}$ of inoculum. Eggs are incubated at $37^{\circ} \mathrm{C}$ for 5 days with daily candling to check for embryo death. Pock lesions measuring in size $0.5-1.5 \mathrm{~mm}$ are observed on the membrane 3-5 days after inoculation, depending on the virulence of the virus $[15,16]$. Another method of isolation of APV requires the excision and homogenization of clinical skin lesions and inoculation of a homogenate supernatant onto a permissive cell culture, such as CEF cells. This results in the formation of CPE within 4-6 days post inoculation, depending on the virus isolate and on the multiplicity of infection (MOI) [4].

\section{Molecular techniques for detection and characterization}

APV are increasingly being detected and characterized by PCR, Restriction fragment length polymorphism (RFLP), Southern blot hybridization, and cycle sequencing, directed at specific genes such as the $4 \mathrm{~b}$ core protein gene $[22,23]$. PCR allows for sensitive and specific detection of viral nucleic acids and has been shown to increase the diagnostic sensitivity for many viral pathogens when compared to culture. A PCR amplicon sequence allows a rapid search for homologous sequences in gene databases, to verify and identify the virus in question and to address phylogenetic relationships. Detection by realtime PCR has been used to identify recombinant APV from individual plaques [74]. This method eliminates the need for amplification and hybridization from the transient dominant protocol and results in significant savings of time at each round of plaque purification [74].

\section{Serological assays}

The conventional serological techniques of passive neutralization and agar-gel immunodiffusion are in continued global use for surveillance and disease control efforts in domestic poultry species [75,76], despite the availability of modern molecular and immunoassay techniques. The tests are time consuming, especially when carried out with large numbers of sera, and sensitivity appears to be low when compared with other detection method, such as enzyme linked immunosorbent assay (ELISA) [77]. ELISA has been described as a non-species specific test approach for birds [78]. It is a faster and easier method to detect antibodies against APV, particularly when large numbers of sera are to be tested. The technique is also more sensitive than the neutralization test $[18,78]$. ELISA protocols have also been developed and used to test the efficacy of FWPV vaccines in commercial and wild bird species where agar-gel immunodiffusion is ineffective due to lack of precipitating antibodies [61,79].

\section{Prevention and treatment}

The challenges of controlling APV disease in poultry are driven by economics, and require strategies that keep cost low while maintaining treatment efficacy. Prophylaxis can be achieved by vaccination [39]. Doyle [80] reported the use of live FWPV or Pigeonpox virus for vaccination against APV infection. Since then, recombinant and live modified vaccines have been developed and used to prevent APV infections in chickens, pigeons, turkeys and quails $[79,81,82]$; Table 2 . These vaccines are very effective and have undoubtedly contributed immensely to the prevention of the disease in commercial poultry farming $[47,81]$. Since different APVs are isolated from a wide range of bird species and since only a few isolates have been characterized, development of a taxon-specific vaccine, directed to all species, has been difficult. Thus, available vaccines are often applied on the basis of experimentation, and more knowledge of molecular biology, pathology and epidemiology of these viruses is necessary to develop vaccines that effectively can protect a range of bird species. As in most viral infections, there is no specific treatment for avian poxvirus infections in birds $[39,83]$. Available treatments include the use of iodine-glycerin application on proliferating skin lesions to aid healing [84], antibiotics to control secondary bacterial infections and vitamin A to aid healing [85].

\section{Avipoxviruses and reticuloendotheliosis virus (REV)}

In the poultry industry, prophylactic measures against FWPV are achieved primarily by vaccination with live FWPV or antigenically similar pigeonpox virus strains produced in CEF cells [60]. In the past two decades, numerous outbreaks have been reported in vaccinated flocks, suggesting that vaccines used against the disease were not effective. In the United States a commercial FWPV vaccine was shown to be contaminated with REV and caused lymphoma among broiler chickens [86]. It has been shown that sequences of REV have been integrated into the DNA of FWPV vaccines as well as in field FWPV isolates [81,87-90]. The integration site is constant, while the size of the integrated fragments differs between various isolates and strains. Two different types of integrated sequences are reported; long terminal repeats (LTRs) with size of approximately 200 to $600 \mathrm{bp}$ and the near-full-length REV provirus of about $800 \mathrm{bp}$ $[87,90,91]$. Most vaccine strains carry only an LTR remnant while most FWPV field isolates carry the nearfull-length provirus. Singh and others [81], however, detected REV LTRs of various lengths in the genome of two commercial FWPV vaccine strains and four field isolates, while several studies have shown that the source of REV infection was REV-contaminated FWPV [86,92-94] and herpesvirus of turkeys vaccines [92,94-97]. Reticuloendotheliosis is a tumorigenic and immunosupressive disease. REV strains have been reported to cause diseases 
Table 2 Avipoxvirus vector-based vaccines licensed for commercial veterinary use

\begin{tabular}{|c|c|c|c|c|c|c|}
\hline Recombinant viral vector & Inserts & Targeted Pathogen & Species & Distributor & Country & References \\
\hline ALVAC & G & Rabies virus & Cats & Merial, Inc. & USA, Canada & [109] \\
\hline ALVAC & $\begin{array}{l}\mathrm{HA} \text { and } \\
\mathrm{F}\end{array}$ & Canine distemper virus & $\begin{array}{l}\text { Dogs, } \\
\text { ferrets }\end{array}$ & Merial, Inc. & $\begin{array}{l}\text { USA, Argentina, Brazil, } \\
\text { Colombia, Canada, Uruguay }\end{array}$ & [132] \\
\hline ALVAC & PrM-E & West-Nile virus & Horses & Merial, Inc. & USA, Canada & {$[133,134]$} \\
\hline ALVAC & $\begin{array}{l}\text { Env, } \\
\text { Gag/ } \\
\text { pol }\end{array}$ & Feline leukaemia virus & Cats & Merial, Inc. & Europe, USA, Canada & [135-137] \\
\hline FWPV & $\mathrm{H} 5 \mathrm{HA}$ & Avian influenza virus & Chickens & Merial, Inc. & USA, Canada & [110] \\
\hline $\begin{array}{l}\text { ALVAC (plus tetanus toxoid } \\
\text { and Carbopol adjuvant) }\end{array}$ & $\mathrm{HA}$ & Equine influenza virus & Horses & Merial, Inc. & Europe, USA & [111] \\
\hline FWPV & $\begin{array}{l}\mathrm{HN} \\
\text { and } \mathrm{F}\end{array}$ & Newcastle disease virus & Chickens & Biomune & USA & {$[13,138]$} \\
\hline $\begin{array}{l}\text { FWPV- Laryngotracheitis } \\
\text { Vaccine }\end{array}$ & $\mathrm{LT}+\mathrm{AE}$ & $\begin{array}{l}\text { Infectious Laryngotracheitis } \\
\text { virus }\end{array}$ & Chickens & $\begin{array}{l}\text { Biomune Co. } \\
\text { (Lenexa, KS, USA) }\end{array}$ & USA & [139] \\
\hline $\begin{array}{l}\text { FWPV- Mycoplasma } \\
\text { gallisepticum Vaccine }\end{array}$ & $M G+A E$ & $\begin{array}{l}\text { Avian Encephalomyelitis and } \\
\text { Mycoplasma gallisepticum }\end{array}$ & Chickens & Biomune Co. & USA & [140] \\
\hline
\end{tabular}

Note: HA from influenza virus H5; HA, hemagglutinin; HN, haemagglutinin-neuraminidase protein; ALVAC, attenuated canarypox virus; FWPV, fowlpox virus; $\mathrm{F}$, fusion protein; G, glycoprotein G; Env, envelope glycoprotein; Gag, group specific antigen; Pro, protease; prM-E, pre-membrane and envelope proteins; MG+AE, Mycoplasma gallisepticum + Avian Encephalomyelitis; LT+AE, Laryngotracheitis virus+Avian Encephalomyelitis.

characterized by chronic lymphoma, non-neoplastic lesions and a runting-stunting syndrome in chickens, turkeys, and quails $[98,99]$. REV are group of avian retroviruses and representatives include the defective REV-T and the non-defective REV-A, spleen necrosis virus (SNV), duck infectious anemia virus, and chick syncytial virus (CSV) [98]. The presence of REV in FWPV vaccines and the failure of currently used FWPV vaccines to evoke high level immunological protection against field challenge of FWPVs are of major concern to the poultry industry [100], which emphasizes the need for research into alternative vaccines.

\section{Avipoxviruses as vaccine vectors}

In 1796 Edward Jenner [101] published his landmark findings that vaccination of humans with cowpox virus could prevent infection with variola virus, the causative agent of smallpox [101,102]. This traditional vaccine technology, based on live viruses and immunological cross protection, has given rise to a wide range of effective vaccines against a wide variety of infectious agents, both in veterinary and human medicine. However, the emergence of new deadly human pathogens and cancers, have proven less amenable to the application of traditional vaccine platforms, indicating the need for new approaches. The use of a live virus vector represent an attractive way to deliver and present vaccine antigens that may offer advantages over traditional platforms, by improving the quality and strength of the immune response, such as in the case of HIV-1 where two different strains of vaccinia virus have been used as vectors. The NYVAC vector has been shown to induce the CD4 ${ }^{+} \mathrm{T}$ cell-dominant response, whereas modified vaccinia virus Ankara (MVA) induces a stronger $\mathrm{CD} 8^{+} \mathrm{T}$ cell response with accompanying $\mathrm{CD} 4^{+} \mathrm{T}$ cell responses that are required for protection [103]. Although this assertion remains unproven (there are to date no virally vectored vaccines licensed for human use), virally vectored vaccines offer an avenue of possibilities, either as homologous regimens, or as heterologous (prime-boost) regimens in which different serotypes of a given vector, different vectors or vectors and traditional technologies such as recombinant protein in adjuvant are administered sequentially.

Currently, representatives of a wide range of virus families are under intensive development as vaccine vectors for human or veterinary use. Of these, FWPV and CNPV appear to be of great interest as vectors, and some veterinary APV-vectored vaccines are already licensed and in commercial use in North America, South America and Europe (Table 2). The most important characteristics of APVs as vaccine vectors are that unlike most other DNA viruses, APV replicate in the cytoplasm of the infected cell and enzymatic functions used for transcription and replication are provided by the virus itself. This has several consequences regarding the use of these viruses as vaccine vectors. For example, APV promoters must be used for efficient transcription of recombinant genes and as APV transcripts are not spliced, genes cloned into APV vectors cannot contain introns [70,104]. Other reasons include (1) their ability to accommodate and effectively express large amounts of foreign DNA or multiple genes that encode antigens [47], (2) their inability to conduct a full replication cycle in non-avian species [105-107], (3) antisera against orthopoxviruses do not neutralize APV and thus, prior 
exposure to vaccinia virus (i.e., vaccination against smallpox) and exposure to other orthopoxviruses such as cowpox virus does not impact the immunogenicity of FWPV and CNPV vectors, and (4) the fact that FWPV and CNPV do not elicit high levels of neutralizing antibodies, which means that their vectors can be used multiple times without the diminished potency usually seen with repeated use of vaccinia virus vectors. This attribute is of crucial importance for a therapeutic vaccine, requiring repeated booster shots [108].

APV-vectored vaccines have been used as vaccines against several animal infections including West Nile virus (WNV), canine distemper virus, feline leukemia virus, rabies virus, and equine influenza virus [109]; Table 2. Notably among them is the Trovac AI H5, a recombinant FWPV that express the $\mathrm{H} 5$ antigen of avian influenza virus. This product has had a conditional license for emergency use for chickens in the United States since 1998 and has been widely used in Central America, with over 2 billion doses administered [110]. ALVAC vectored vaccines have recently been registered for veterinary use in the European Union (Proteq-Flu) [111] and the United States (Recombitek). The equine influenza virus vaccine with CNPV vector expresses the hemagglutinin genes of the H3N8 Newmarket and Kentucky strains and contains a polymer adjuvant (Carbopol; Merial Ltd.). With the induction of both cell-mediated and humoral immunity, it is claimed that the vaccine produced sterile immunity 2 weeks after the second of two doses. The new vaccine is also designed to protect horses against the highly virulent N/5/03 American strain of equine influenza virus and to prevent the virus from spreading through the elimination of viral shedding.

Despite these notable advances in APV-vectored vaccine development, the list of licensed viral vectored vaccines for human medicine is short, with only a few vaccines that have entered clinical trials [112]; Table 3.
This may be in part owing to stringent safety requirements that must be met for viruses, that in their natural state have the potential to be human pathogens, to be used as viral vaccine vectors that may replicate in vivo in a manner similar to their wild-type parental viruses. Another reason may be fear of risk of spontaneous recombination between virus vectors and naturally occurring viral relatives in the ecosystems in which the vaccine is used. Even if APVs are not generally expected to replicate in mammals, the vaccine vectors may reach bird populations via animal populations. It is also possible that the vector, through spontaneous recombination and mutation events, may restore its replication competence. To cater for this, the aim during design and development of a virus vector is always to introduce at least two gene deletions crucial for viral to undergo a full replication cycle to assure a very low probability that replication competence could be restored. To our knowledge, such reversions have not been identified in clinical trials of APV-vectored vaccines. In addition to concerns regarding reversion or recombination, another safety signal was recently identified in an in vitro experiment that showed APV replication in cell clones derived from embryonic bovine trachea [53] and Syrian baby hamster kidney (BHK) cells. In this experiment, infectious IMV was observed; indicating complete virus replication had taken place [54]. These findings are in contrast to the general dogma that APVs are restricted to infection of cells of avian origin, and are an indication that there is still more to learn about the replication mechanisms and virus-host interactions of these viruses, including evasion of immune responses, cell tropism and host range mechanisms.

\section{Conclusions}

APVs cause disease of economical importance for the poultry industry, and also in pet and wild birds. Thus,

Table 3 Avipoxvirus vector based vaccines and prime-boost immunization regimes in clinical development for human use

\begin{tabular}{|c|c|c|c|c|c|c|}
\hline Recombinant viral vector & $\begin{array}{l}\text { Targeted } \\
\text { pathogen/ } \\
\text { disease }\end{array}$ & Inserts & Vaccine details & Developer/Sponsors & $\begin{array}{l}\text { Clinical } \\
\text { phase }\end{array}$ & References \\
\hline $\begin{array}{l}\text { ALVAC containing the gene } \\
\text { encoding HIV-1 gp160, and } \\
\text { protein gp120 }\end{array}$ & HIV-1 & gp160 and gp120 & $\begin{array}{l}\text { ALVAC-HIV VCP1521 prime } \\
\text { and AIDSVAX-gp120 subtype } \\
\text { B/E boost }\end{array}$ & $\begin{array}{l}\text { U.S. Army Medical } \\
\text { Research and Materiel } \\
\text { Command }\end{array}$ & III & [141] \\
\hline $\begin{array}{l}\text { ALVAC-HIV (VCP1452) and LIPO- } \\
5+\text { VCP1452 }\end{array}$ & HIV-1 & LIPO-5 & ALVAC-HIV (VCP1452) LIPO-5 & $\mathrm{NIH}$ & $|/| \mid$ & [142] \\
\hline $\begin{array}{l}\text { VACV and ALVAC or FWPV with } \\
\text { or without combination therapy }\end{array}$ & Cancer & $\begin{array}{l}\text { CEA } \\
\text { (pancarcinoma) }\end{array}$ & $\begin{array}{l}\text { TRICOM vectors co-express } \\
\text { B7.1, ICAM1 and LFA3 }\end{array}$ & $\mathrm{NIH}$ & $|/| \mid$ & [143] \\
\hline FWPV (FP9) & Malaria & $\begin{array}{l}\text { Circumsporozoite } \\
\text { (CSP) protein }\end{array}$ & $\begin{array}{l}\text { Attenuated FP9 and } \\
\text { Circumsporozoite (CSP) } \\
\text { protein }\end{array}$ & $\begin{array}{l}\text { Gates Malaria } \\
\text { Partnership }\end{array}$ & । & [144] \\
\hline
\end{tabular}

HIV-1, human immunodeficiency virus 1; ALVAC, attenuated canarypox virus; gp160, glycoprotein 160; gp120, glycoprotein 120; VACV, vaccinia virus; FWPV, fowlpox virus; CEA, carcinoembryonic antigen; TRICOM, triad of costimulatory molecules; ICAM1, intercellular adhesion molecule 1; LFA3, lymphocyte functionassociated antigen 3; LIPO-5, Lipopeptide 5; CSP, circumsporozoite protein; FP9, attenuated fowlpox virus 9; NIH, US National Institutes of Health. 
prophylactic measures, such as vaccination, will always be required, and there is a need for more efficient and safe vaccines. One promising approach is the use of APVs as vectors for recombinant vaccines, increasing the efficacy and avoiding the potential contamination with REV and other agents. Many recombinant APV constructs are already licensed for use in veterinary medicine, and a range of vaccine candidates are currently being tested for use in vaccines against numerous infectious diseases in animals and man. Thus, it is likely that recombinant APV-vectored vaccines in the near future will also be used against human diseases. APVs have many advantages as vaccine vectors, including a large genome which allows for the inclusion of many heterologous genes, such as genes coding for antigens, cytokines and other immuno-modulating factors. The major safety argument for using APVs rather than vaccinia virus or other mammalian viruses as vectors, is that APVs are not zoonotic and are not able to conduct a full replication cycle in mammals. However, it was recently shown that FWPV was able to replicate and produce progeny virions in some established mammalian cell lines. This illustrates the fact that general knowledge of APVs is scarce. Indeed, only a few isolates have been characterized and classified. New molecular tools have led to a greater resolution of factors and mechanisms that restrict viruses to certain hosts, for example HIV and SARS. Mechanisms of host restriction, pathogenicity, host immunity and viral immune evasion strategies are of crucial importance regarding use of APVs as vectors in multispecies-targeted vaccines. A good understanding of the molecular properties of APVs underpins the development of safe APVvectored vaccines.

\begin{abstract}
Abbreviations
ALVAC: attenuated canarypox virus CNPV; APVs: Avipoxviruses; ATCC: American Type Culture Collection; BHK: Baby hamster kidney; CAM: chorioallantoic membrane; CEA: carcinoembryonic antigen; CEF: chicken embryo fibroblast; CHO: Chinese hamster ovary; CPE: cytopathic effect; CSP: circumsporozoite protein; EEV: extracellular enveloped virus; ELISA: enzyme linked immunosorbent assay; Env: envelope glycoprotein; F: fusion protein; FP9: attenuated fowlpox virus 9; FWPV: fowlpox virus; G: glycoprotein G; Gag: group specific antigen; gp120: glycoprotein 120; gp160: glycoprotein 160; HA: hemagglutinin; HA5: Hemagglutinin from influenza virus H5; HIV-1: human immunodeficiency virus 1; HN: haemagglutinin-neuraminidase protein; ICAM1: intercellular adhesion molecule 1; IEV: intracellular enveloped virus; IMV: intracellular mature virus; ITRs: inverted terminal repeats; IV: immature virus; LFA3: lymphocyte function-associated antigen 3; LIPO-5: Lipopeptide 5; MDV: Marek's disease virus; MOI: multiplication of infection; $\mathrm{NIH}$ : US National Institutes of Health; PCR: polymerase chain reaction; prM-E: pre-membrane and envelope proteins; Pro: protease; PTA: phosphotungstic acid; REV: Reticuloendotheliosis virus; RFLP: restriction fragment length polymorphism; TEM: transmission electron microscopy; TLR: Toll-like receptor; TRICOM: triad of costimulatory molecules; VACV: vaccinia virus; WNV: West Nile virus;
\end{abstract}

\section{Acknowledgements}

This work was supported by National Veterinary Institute, Oslo, Norway grant for the Strategic institute program \#1869071. We are grateful to Gunnar Holt,
National Veterinary Institute, Oslo, for letting us use the pictures of clinical avipoxvirus cases and to Duncan Colquhoun for reviewing the manuscript.

\section{Author details}

${ }^{1}$ National Veterinary Institute, Ullevålsveien 68, N-0106 Oslo, Norway. ${ }^{2}$ Section of Arctic Veterinary Medicine, Department of Food Safety and Infection Biology, Norwegian School of Veterinary Science, Stakkevollveien 23, N-9010 Tromsø, Norway. ${ }^{3}$ Gen $\varnothing k$-Centre for Bio-safety, The Science Park, Breivika, PO Box 6418, N-9294 Tromsø, Norway.

\section{Authors' contributions}

SCW and MT contributed equally in drafting and reviewing the manuscript. All authors have read and approved the final manuscript.

\section{Competing interests}

The authors declare that they have no competing interests.

Received: 9 November 2010 Accepted: 3 February 2011

Published: 3 February 2011

\section{References}

1. Fauquet CM, Mayo MA, Maniloff J, Desselberger U, Ball LA, Virus Taxonomy: VIIIth Report of the International Committee on Taxonomy of Viruses". Elsevier Academic Press; 2005.

2. Bohls RL, Linares JA, Gross SL, Ferro PJ, Silvy NJ, Collisson EW: Phylogenetic analyses indicate little variation among reticuloendotheliosis viruses infecting avian species, including the endangered Attwater's prairie chicken. Virus Res 2006, 119:187-94.

3. Bailey TA, Silvanose C, Manvell R, Gough RE, Kinne J, Combreau O, Launay F: Medical dilemmas associated with rehabilitating confiscated houbara bustards (Chlamydotis undulata macqueenii) after avian pox and paramyxovirus type 1 infection. J Wildl Dis 2002, 38:518-32.

4. Tripathy DN, Schnitzlein WM, Morris PJ, Janssen DL, Zuba JK, Massey G, Atkinson CT: Characterization of poxviruses from forest birds in Hawaii. J Wildl Dis 2000, 36:225-30.

5. Bollinger O: Ueber Epithelioma contagiosum beim havshuhn und die Sogenannten pocken des Geflugels. Archive fur pathologische Anatomie und Physiologie und fur klinishe medizin 1873, 58:349-361.

6. Bolte AL, Meurer J, Kaleta EF: Avian host spectrum of avipoxviruses. Avian Pathol 1999, 28:415-432.

7. Afonso CL, Tulman ER, Lu Z, Zsak L, Kutish GF, Rock DL: The genome of fowlpox virus. J Virol 2000, 74:3815-3831.

8. Tulman ER, Afonso CL, Lu Z, Zsak L, Kutish GF, Rock DL: The genome of canarypox virus. J Virol 2004, 78:353-66.

9. Boyle DB: Genus Avipoxvirus. In Poxviruses. Edited by: Mercer AA, Schmidt A, Weber O. Birkhauser Verlag, Basel; 2007:217-251.

10. Binns MM, Avery R: Developing novel vaccines. Poultry International 1986, 28:12-14.

11. Binns MM, Boursnell MEG, Tomley FM, Mockett APA, Cavanagh D, Brown TDK: Prospect for a novel genetically engineered vaccine against infectious bronchitis. Israeli J Vet Med 1986, 42:124-127.

12. Boyle DB, Coupar BE: Construction of recombinant fowlpox viruses as vectors for poultry vaccines. Virus Res 1988, 10:343-56.

13. Taylor J, Weinberg R, Kawaoka Y, Webster RG, Paoletti E: Protective immunity against avian influenza induced by a fowlpox virus recombinant. Vaccine 1988, 6:504-8

14. Beard CW, Schnitzlein WM, Tripathy DN: Protection of chickens against highly pathogenic avian influenza virus $(\mathrm{H} 5 \mathrm{~N} 2)$ by recombinant fowlpox viruses. Avian Dis 1991, 35:356-9.

15. Cox WR: Avian pox infection in a Canada goose (Branta canadensis). J Wildl Dis 1980, 16:623-626.

16. Holt G, Krogsrud J: Pox in wild birds. Acta Vet Scand 1973, 14:201-203.

17. Sadasiv EC, Chang PW, Gulka G: Morphogenesis of canary poxvirus and its entrance into inclusion bodies. Am J Vet Res 1985, 46:529-35, 1985.

18. Weli SC, Okeke MI, Tryland M, Nilssen O, Traavik T: Characterization of avipoxviruses from wild birds in Norway. Can J Vet Res 2004, 68:140-5.

19. Fenner F, Burnet FM: A short description of the poxvirus group (vaccinia and related viruses). Virology 1957, 4:305-314, 1957.

20. Fenner F: Adventures with poxviruses of vertebrates. FEMS Microbiology Reviews 2000, 24:123-133. 
21. Huw Lee L, Hwa Lee K: Application of the polymerase chain reaction for the diagnosis of fowl poxvirus infection. J Virol Methods 1997, 63:113-9.

22. Luschow D, Hoffmann T, Hafez HM: Differentiation of avian poxvirus strains on the basis of nucleotide sequences of $4 \mathrm{~b}$ gene fragment. Avian Dis 2004, 48:453-462.

23. Weli SC, Traavik T, Tryland M, Coucheron DH, Nilssen O: Analysis and comparison of the $4 \mathrm{~b}$ core protein gene of avipoxviruses from wild birds: evidence for interspecies spatial phylogenetic variation. Arch Virol 2004, 149:2035-2046.

24. Carter JKY, Cherville NF: Isolation of surface tubules of fowlpoxvirus. Avian Dis 1981, 25:454-462.

25. Andrews C, Pereira HG: Virus vertebrates. Wildy publishing Tindall, London, 4 1978, 356-389, 1978

26. Tantwai HH, Al Falluji MM, Shony MO: Heat-selected mutants of pigeon poxvirus. Acta Virol 1979, 23:249-252.

27. Laidlaw SM, Skinner MA: Comparison of the genome sequence of FP9, an attenuated, tissue culture-adapted European strain of Fowlpox virus, with those of virulent American and European viruses. J Gen Virol 2004, 85:305-22.

28. Seet BT, Johnston JB, Brunetti CR, Barrett JW, Everett $\mathrm{H}$, Cameron $\mathrm{C}$, Sypula J, Nazarian SH, Lucas A, McFadden G: Poxviruses and immune evasion. Annu Rev Immunol 2003, 21:377-423.

29. Johnston JB, McFadden G: Technical knockout: understanding poxvirus pathogenesis by selectively deleting viral immunomodulatory genes. Cell Microbiol 2004, 9:695-705.

30. Perkus ME, Goebel SJ, Davis SW, Johnson GP, Limbach K, Norton EK, Paoletti E: Vaccinia virus host range genes. Virology 1990, 179:276-286.

31. Drillien $R$, Spehner $D$, Kirn A: Host range restriction of vaccinia virus in Chinese hamster ovary cells: relationship to shutoff of protein synthesis. J Virol 1978, 28:843-850.

32. Gillard S, Spehner D, Drillien R, Kim A: Localization and sequence of a vaccinia virus gene required for multiplication in human cells. Proc Natl Acad Sci USA 1986, 83:5573-5577.

33. Gillard S, Spehner D, Drillien R: Mapping of a vaccinia host range sequence by insertion into the viral thymidine kinase gene. J Virol 1985 53:316-318.

34. Ramsey-Ewing A, Moss B: Apoptosis induced by a postbinding step of vaccinia virus entry into Chinese hamster ovary cells. Virology 1998 242:138-149.

35. Hsiao JC, Chung CS, Drillien R, Chang W: The cowpox virus host range gene, CP77, affects phosphorylation of elF2 and vaccinia viral translation in apoptotic HeLa cells. Virology 2004, 329:99-212.

36. Oguiura N, Spehner D, Drillien R: Detection of a protein encoded by the vaccinia virus $C 7 \mathrm{~L}$ open reading frame and study of its effect on virus multiplication in different cell lines. J Gen Virol 1993, 74:1409-1413.

37. Spehner D, Gillard S, Drillien R, Kirn A: A cowpox virus gene required for multiplication in Chinese hamster ovary cells. J Virol 1998, 62:1297-1304.

38. Amano H, Morikawa S, Shimizu H, Shoji I, Kurosawa D, Matsuura Y, Miyamura T, Ueda Y: Identification of the canarypox virus thymidine kinase gene and insertion of foreign genes. Virology 1999, 256:280-290.

39. Boulanger D, Smith T, Skinner MA: Morphogenesis and release of fowlpox virus. J Gen Virol 2000, 81:675-87.

40. Mann BA, Huang JH, Li P, Chang HC, Slee RB, O'Sullivan A, Anita M, Yeh N, Klemsz MJ, Brutkiewicz RR, Blum JS, Kaplan MH: Vaccinia virus blocks Stat1-dependent and Stat1-independent gene expression induced by type I and type II interferons. J Interferon Cytokine Res 2008, 28:367-80.

41. Bowie AG, Unterholzner L: Viral evasion and subversion of patternrecognition receptor signalling. Nature Reviews Immunology 2008, 8:911-922.

42. Alcami A: New insights into the subversion of the chemokine system by poxviruses. Eur I Immunol 2007, 37:880-3.

43. Alcamí A, Smith GL: A soluble receptor for interleukin-1 beta encoded by vaccinia virus: a novel mechanism of virus modulation of the host response to infection. Cell 1992, 71:153-67.

44. Dasgupta A, Hammarlund E, Slifka MK, Früh K: Cowpox Virus Evades CTL Recognition and Inhibits the Intracellular Transport of MHC Class I Molecules. The Journal of Immunology 2007, 178:1654-1661

45. Antoniou AN, Powis SJ: Pathogen evasion strategies for the major histocompatibility complex class I assembly pathway. Immunology 2008 124:1-12.
46. Boehmer PE, Lehman IR: Herpes simplex virus DNA replication. Annu Rev Biochem 1997, 66:347-84

47. Paoletti E: Application of pox virus vectors: an update. Proc Natl Acad SC USA 1996, 93:11349-11353.

48. Ghildyal N, Schnitzlein WM, Tripathy DN: Genetic and antigenic differences between fowl pox and quail pox viruses. Arch Virol 1989, 106:85-92

49. Schnitzlein WM, Ghildyal N, Tripathy DN: A rapid method for identifying the thymidine kinase genes of avipoxviruses. J Virol Methods 1988 20:341-352.

50. Yamaguchi T, Kaplan SL, Wakenell P, Schat KA: Transactivation of latent Merak's disease herpesvirus gene in QT35, a quail fibroblast cell line, by herpesvirus of turkeys. J Virol 2000, 74:10176-10186.

51. Mayr A, Mahnel H: Characterization of a fowlpox virus isolated from a rhinoceros. Arch Gesamte Virusforsch 1970, 31:51-60.

52. Nelson JB: The behaviour of poxviruses in respiratory tract: IV. The nasal instillation of fowlpoxvirus in chickens and in mice. J Exp Med 1941 31:203-12

53. Sainova IV, Kril Al, Simeonov KB, Popova TP, Ivanov IG: Investigation of the morphology of cell clones, derived from the mammalian EBTr cell line and their susceptibility to vaccine avian poxvirus strains FK and Dessau. J Virol Methods 2005, 124:37-40.

54. Weli SC, Nilssen O, Traavik T: Avipoxvirus multiplication in a mammalian cell line. Virus Res 2005, 109:39-49.

55. Hatano Y, Yoshida M, Uno F, Yoshida S, Osafune N, Ono K, Yamada M, Nii S Budding of fowlpox and pigeonpox viruses at the surface of infected cells. J Electron Microsc (Tokyo) 2001, 50:113-24.

56. Weli SC, Nilssen $\varnothing$, Traavik T: Morphogenesis of fowlpox virus in a baby hamster kidney cell line. Med Electron Microsc 2004, 37:225-235.

57. Smith GL, Law M: The exit of vaccinia virus from infected cells. Virus Res 2004, 106:189-97.

58. Somogyi P, Frazier J, Skinner MA: Fowlpox virus host range restriction: gene expression, DNA replication, and morphogenesis in non-permissive mammalian cells. Virology 1993, 197:439-444.

59. Stannard LM, Marais D, Kow D, Dumbell KR: Evidence for incomplete replication of a penguin poxvirus in cells of mammalian origin. $J$ Gen Virol 1998, 79:1637-46.

60. Tripathy DN, Reed WM: Poxvirus. In Diseases of Poultry. Edited by: Saif YM, Barnes HJ, Glisson JR, Fadly AM, McDougald LR, Swayne DE. lowa State University Press, Ames, IA; 2003:253-269.

61. Kim T, Tripathy DN: Evaluation of pathogenicity of avian poxvirus isolates from endangered Hawaiian wild birds in chickens. Avian Dis 2006, 50:288-91

62. Boosinger TR, Winterfield RW, Feldman DS, Dhillon AS: Psittacine poxvirus: virus isolation and identification, transmission and cross-challenge studies in parrots and chickens. Avian Dis 1982, 26:437-444.

63. Mayr A, Mahnel H, Munz E: Systematiserung und differenzier ung der pockenviren. Zbl Vet Med B 1962, 19:69-88.

64. Mayr A: Neue verfahren fürdie differenzierung der geflügelpockenviren. Berl Münch Tierärztl Wochenschr 1963, 76:316-324.

65. Chung YS, Spradbrow PB: Studies on poxvirus isolated from a magpie in Queensland. Australian. Vet J 1977, 53:334-336.

66. Jarmin S, Manvell R, Gough RE, Laidlaw SM, Skinner MA: Avipoxvirus phylogenetics: identification of a PCR length polymorphism that discriminates between the two major clades. J Gen Virol 2006 , 87:2191-2201.

67. Carulei O, Douglass N, Williamson AL: Phylogenetic analysis of three genes of Penguinpox virus corresponding to Vaccinia virus G8R (VLTF-1), $\mathrm{A} 3 \mathrm{~L}$ (P4b) and $\mathrm{H} 3 \mathrm{~L}$ reveals that it is most closely related to Turkeypox virus, Ostrichpox virus and Pigeonpox virus. Virol J 2009, 6:52.

68. Proctor $\mathrm{H}$, Owens I: Mites and birds: Diversity, parasitism and coevolution. Trends in Ecology and Evolution 2000, 15:358-364.

69. Clubb SL: Avian pox in cage and aviary birds. In Zoo and wild animal medicine. Edited by: Fowler ME. WB Saunders Company, Philadelphia, Pennsylvania; 1986:213-219.

70. Moss B: Vaccinia and other poxvirus expression vectors. Curr Opin Biotechnol 1992, 3:518-522.

71. Walker MH, Rup BJ, Rubin AS, Bose HR Jr: Specificity in the immunosuppression induced by avian reticuloendotheliosis virus. Infect Immun 1983, 40:225-35. 
72. Pennycott TW: Scaly leg, papillomas and pox in wild birds. Vet Rec 2003 152:444.

73. Riper C van, Forrester DJ: Avian pox. In Infectious diseases of wild birds. Edited by: Thomas NJ, Hunter DB, Atkinson CT. Blackwell Publishing, Ames, lowa, USA; 2007:131-176

74. Boyle DB, Anderson MA, Amos R, Voysey R, Coupar BE: Construction of recombinant fowlpox viruses carrying multiple vaccine antigens and immunomodulatory molecules. Biotechniques 2004, 37:104-6, 108-11.

75. Baxi MK, Oberoi MS: Comparative evaluation of cell culture-adapted and chicken embryo-adapted fowl pox vaccine strains. Avian Dis 1999, 43:16-21.

76. Tadese T, Potter EA, Reed WM: Development of a mixed antigen agar gel enzyme assay (AGEA) for the detection of antibodies to poxvirus in chicken and turkey sera. J Vet Med Sci 2003, 65:255-8.

77. Smits JE, Tella JL, Carrete M, Serrano D, López G: An epizootic of avian pox in endemic short-toed larks (Calandrella rufescens) and Berthelot's pipits (Anthus berthelotti) in the Canary Islands, Spain. Vet Pathol 2005, 42:59-65.

78. Buscaglia C, Bankowski RA, Miers L: Cell-culture virus-neutralization test and enzyme-linked immunosorbent assay for evaluation of immunity in chickens against fowlpox. Avian Dis 1985, 29:672-680.

79. Wang J, Meers J, Spradbrow PB, Robinson WF: Evaluation of immune effects of fowlpox vaccine strains and field isolates. Vet Microbiol 2006, 116:106-19.

80. Doyle TM: Immunisation of fowls against fowlpox by means of pigeon pox virus. J Comparative Pathol 1930, 43:40-45

81. Singh P, Kim TJ, Tripathy DN: Re-emerging fowlpox: evaluation of isolates from vaccinated flocks. Avian Pathol 2000, 29:449-55.

82. Taylor J, Tartaglia J, Rivière M, Duret C, Languet B, Chappuis G, Paoletti E: Applications of canarypox (ALVAC) vectors in human and veterinary vaccination. Dev Biol Stand 1994, 82:131-5.

83. Redig PT: Infectious diseases. In First Aid and case of wild birds. Edited by: Cooper JE, Eley JT. Davis and Charles Limited, Newton Abbot, UK; 1979:118-139.

84. van Heelsbergen T: Handbuch der Geflugelkrankheiten und der Geflugelzucht. Stuttgart, Ferdinand Enke Verlag; 1929, 230-262.

85. Cooper JE: Veterinary aspect of captive bird of prey. Standfast Press, Cherington, UK; 1985, supplement: 256.

86. Fadly AM, Witter RL, Smith EJ, Silva RF, Reed WM, Hoerr FJ, Putnam MR: An outbreak of lymphomas in commercial broiler breeder chickens vaccinated with a fowlpox vaccine contaminated with reticuloendotheliosis virus. Avian Pathol 1996, 25:35-47.

87. Singh $P$, Schnitzlein WM, Tripathy DN: Reticuloendotheliosis virus sequences within the genomes of field strains of fowlpox virus display variability. J Virol 2003, 77:5855-62.

88. García M, Narang N, Reed WM, Fadly AM: Molecular characterization of reticuloendotheliosis virus insertions in the genome of field and vaccine strains of fowl poxvirus. Avian Dis 2003, 47:343-54

89. Hertig C, Coupar BE, Gould AR, Boyle DB: Field and vaccine strains of fowlpox virus carry integrated sequences from the avian retrovirus, reticuloendotheliosis virus. Virology 1997, 235:367-76.

90. Kim TJ, Tripathy DN: Reticuloendotheliosis virus integration in the fowl poxvirus genome: not a recent event. Avian Dis 2001, 45:663-9.

91. Diallo IS, Mackenzie MA, Spradbrow PB, Robinson WF: Field isolates of fowlpox virus contaminated with reticuloendotheliosis virus. Avian Pathol 1998, 27:60-6.

92. Bagust TJ, Dennett DP: Reticuloendotheliosis virus: experimental infection of poultry and immunofluorescent identification of Australian isolates. Aust Vet J 1977, 53:506-8.

93. Bendheim U: A neoplastic disease in turkey following fowlpox vaccination. Refu Vet 1973, 30:35-41.

94. Jackson CA, Dunn SE, Smith DI, Gilchrist PT, Macqueen PA: Proventriculitis, "nakanuke" and reticuloendotheliosis in chickens following vaccination with herpesvirus of turkeys (HVT). Aust Vet J 1977, 53:457-9.

95. Kawamura H, Wakabayashi T, Yamaguchi S, Taniguchi T, Takayanagi N: Inoculation experiment of Marek's disease vaccine contaminated with a reticuloendotheliosis virus. Natl Inst Anim Health Q (Tokyo) 1976, 16:135-40.

96. Koyama H, Suzuki Y, Ohwada Y, Saito Y: Reticuloendotheliosis group virus pathogenic to chicken isolated material infected with turkey herpesvirus (HVT). Avian Dis 1977, 20:429-434.
97. Yuasa N, Yoshida I, Taniguchi T: Isolation of a reticuloendotheliosis virus from chickens inoculated with Marek's disease vaccine. Natl Inst Anim Health Q (Tokyo) 1976, 16:141-51.

98. Witter RL, Fadly AL: Reticuloendothelosis. In Diseases of poultry. 11 edition Edited by: Saif YM, Barnes HJ, Glisson J, McDougald LR, Swayne D. lowa State University Press, Ames, IA; 2003:517-535.

99. Payne LN: Retrovirus-induced disease in poultry. Poult Sci 1998 77:1204-12.

100. Fatunmbi OO, Reed WM: Evaluation of a commercial quail pox vaccine (Bio-Pox Q) for the control of "variant" fowl poxvirus infections. Avian Dis 1996, 40:792-7.

101. Jenner E: An inquiry into the causes and effects of the variolae vaccinae, a disease discovered in some of the western counties of England, particularly Gloucestershire and known by the name of the cow pox Law, London; 1798.

102. Cook GC: The smallpox saga and the origin(s) of vaccination. J Royal Soc Health 1996, 116:253-255, 1996

103. Mooij P, Balla-Jhagjhoorsingh SS, Koopman G, Beenhakker N, van Haaften $P$, Baak I, Nieuwenhuis IG, Kondova I, Wagner R, Wolf H, Gómez CE, Nájera JL, Jiménez V, Esteban M, Heeney JL: Differential CD4+ versus CD8+ T-cell responses elicited by different poxvirus-based human immunodeficiency virus type 1 vaccine candidates provide comparable efficacies in primates. J Virol 2008, 82:2975-88.

104. Perkus ME, Tartaglia J, Paoletti E: Poxvirus-based vaccine candidates for cancer, AIDS, and other infectious diseases. J Leukoc Biol 1995, 58:1-13, 1995

105. Boyle $D$, Heine $H$ : Recombinant fowlpox virus vaccines for poultry. Immunol Cell Biol 1993, 71:391-397.

106. Tartaglia J, Perkus ME, Taylor J, Norton EK, Audonnet JC, Cox WI, Davis SW van der Hoeven J, Meignier B, Riviere M, Languet B, Paoletti E: NYVAC: a highly attenuated strain of vaccinia virus. Virology 1992, 188:217-232.

107. Taylor J, Weinberg R, Languet B, Desmettre P, Paoletti E: Recombinant fowlpox virus inducing protective immunity in non-avian species. Vaccine 1988, 6:497-503.

108. Marshall JL, Gulley JL, Arlen PM, Beetham PK, Tsang KY, Slack R, Hodge JW, Doren S, Grosenbach DW, Hwang J, Fox E, Odogwu L, Park S, Panicali D, Schlom J: Phase I study of sequential vaccinations with fowlpox-CEA (6D)-TRICOM alone and sequentially with vaccinia-CEA (6D)-TRICOM, with and without granulocyte-macrophage colony-stimulating factor, in patients with carcinoembryonic antigen-expressing carcinomas. J Clin Oncol 2005, 23:720-731

109. Taylor J, Meignier B, Tartaglia J, Languet B, VanderHoeven J, Franchini G, Trimarchi C, Paoletti E: Biological and immunogenic properties of a canarypox-rabies recombinant, ALVAC-RG (vCP65) in non-avian species. Vaccine $1995,13.539-49$

110. Bublot M, Pritchard N, Swayne DE, Selleck P, Karaca K, Suarez DL, Audonnet JC, Mickle TR: Development and use of fowlpox vectored vaccines for avian influenza. Ann N Y Acad Sci 2006, 1081:193-201.

111. Minke JM, Audonnet JC, Fischer L: Equine viral vaccines: the past, present and future. Vet Res 2004, 35:425-43.

112. Clinical Trials database. [http://clinicaltrials.gov].

113. Diallo IS, Taylor J, Gibson J, Hoad J, De Jong A, Hewitson G, Corney BG, Rodwell BJ: Diagnosis of a naturally occurring dual infection of layer chickens with fowlpox virus and gallid herpesvirus 1 (infectious laryngotracheitis virus). Avian Pathol 2010, 39:25-30.

114. Shivaprasad HL, Kim T, Tripathy D, Woolcock PR, Uzal F: Unusual pathology of canary poxvirus infection associated with high mortality in young and adult breeder canaries (Serinus canaria). Avian Pathol 2009, 38:311-6.

115. Johnson BJ, Castro AE: Canary pox causing high mortality in an aviary. Am Vet Med Assoc 1986, 189:1345-7.

116. Reed WM, Schrader DL: Pathogenicity and immunogenicity of mynah pox virus in chickens and bobwhite quail. Poult Sci 1989, 68:631-8.

117. Wilson $\mathrm{MH}$, Crawford JA: Poxvirus in scaled quail and prevalences of poxvirus-like lesions in northern bobwhites and scaled quail from Texas. J Wildl Dis 1988, 24:360-3.

118. Pilaski J, Rotschuh L, Encke W: Ein Pockenausbruch in einem Ziervogelbestand des Krefelder Zoologischen Gartens. Verhandlungsberichte des 32. Internationalen Symposiums uber die Erkrankungen der Zoo- und Wildtiere, Eskilstuna 1990, 157-164.

119. Prukner-Radovcić E, Lüschow D, Ciglar Grozdanić I, Tisljar M, Mazija H, Vranesić D, Hafez HM: Isolation and molecular biological investigations of 
avian poxviruses from chickens, a turkey, and a pigeon in Croatia. Avian Dis 2006, 50:440-4.

120. Al Falluji MM, Tantawi HH, Al-Bana A, Al-Sheikhly S: Pox infection among captive peacocks. J Wild Dis 1979, 15:597-600.

121. Terasaki T, Kaneko M, Mase M: Avian poxvirus infection in flamingos (Phoenicopterus roseus) in a zoo in Japan. Avian Dis 2010, 54:955-7.

122. Brower Al, Cigel F, Radi C, Toohey-Kurth K: Beak necrosis in Hungarian partridges (Perdix perdix) associated with beak-bits and avian poxvirus infection. Avian Pathol 2010, 39:223-5.

123. Saito K, Kodama A, Yamaguchi T, Gotoh Y, Sakai H, Fukushi H, Masegi T, Yanai T: Avian poxvirus infection in a white-tailed sea eagle (Haliaeetus albicilla) in Japan. Avian Pathol 2009, 38:485-9.

124. Palade EA, Biro N, Dobos-Kovács M, Demeter Z, Mándoki M, Rusvai M: Poxvirus infection in Hungarian great tits (Parus major): case report. Acta Vet Hung 2008, 56:539-46.

125. Lierz M, Bergmann V, Isa G, Czerny CP, Lueschow D, Mwanzia J, Prusas C, Hafez HH: Avipoxvirus infection in a collection of captive stone curlews (Burhinus oedicnemus). J Avian Med Surg 2007, 21:50-5.

126. Rampin T, Pisoni G, Manarolla G, Gallazzi D, Sironi G: Epornitic of avian pox in common buzzards (Buteo buteo): virus isolation and molecular biological characterization. Avian Pathol 2007, 36:161-5.

127. Grove DM, Zajac AM, Spahr J, Duncan RB Jr, Sleeman JM: Combined infection by avian poxvirus and Collyriclum faba in an American crow (Corvus brachyrhynchos). J Zoo Wildl Med 2005, 36:111-4.

128. Shivaprasad HL, Kim TJ, Woolcock PR, Tripathy DN: Genetic and antigenic characterization of a poxvirus isolate from ostriches. Avian Dis 2002 46:429-36.

129. Raidal SR, Gill JH, Cross GM: Pox in ostrich chicks. Aust Vet J 1996, 73:32-3.

130. Deern SL, Heard DJ, Fox JH: Avian pox in eastern screech owls and barred owls from Florida. J Wildl Dis 1997, 33:323-7.

131. Orós J, Rodríguez F, Rodríguez JL, Bravo C, Fernández A: Debilitating cutaneous poxvirus infection in a Hodgson's grandala (Grandala coelicolor). Avian Dis 1997, 41:481-3.

132. Pardo MC, Bauman JE, Mackowiak M: Protection of dogs against canine distemper by vaccination with a canarypox virus recombinant expressing canine distemper virus fusion and hemagglutinin glycoproteins. Am J Vet Res 1997, 58:833-6.

133. Siger L, Bowen RA, Karaca K, Murray MJ, Gordy PW, Loosmore SM, Audonnet JC, Nordgren RM, Minke JM: Assessment of the efficacy of a single dose of a recombinant vaccine against West Nile virus in response to natural challenge with West Nile virus-infected mosquitoes in horses. Am J Vet Res 2004, 65:1459-62.

134. Minke JM, Siger L, Karaca K, Austgen L, Gordy P, Bowen R, Renshaw RW Loosmore S, Audonnet JC, Nordgren B: Recombinant canarypoxvirus vaccine carrying the $\mathrm{prM} / \mathrm{E}$ genes of West Nile virus protects horses against a West Nile virus-mosquito challenge. Arch Virol Supp/ 2004, 18:221-30.

135. Poulet H, Brunet S, Boularand C, Guiot AL, Leroy V, Tartaglia J, Minke J, Audonnet JC, Desmettre P: Efficacy of a canarypox virus-vectored vaccine against feline leukaemia. Vet Rec 2003, 153:141-5.

136. Tartaglia J, Jarrett O, Neil JC, Desmettre P, Paoletti E: Protection of cats against feline leukemia virus by vaccination with a canarypox virus recombinant, ALVAC-FL. J Virol 1993, 67:2370-5.

137. Hofmann-Lehmann R, Tandon R, Boretti FS, Meli ML, Willi B, Cattori V, Gomes-Keller MA, Ossent P, Golder MC, Flynn JN, Lutz H: Reassessment of feline leukaemia virus (FeLV) vaccines with novel sensitive molecular assays. Vaccine 2006, 24:1087-94

138. Sun HL, Wang YF, Tong GZ, Zhang PJ, Miao DY, Zhi HD, Wang M, Wang M: Protection of chickens from Newcastle disease and infectious laryngotracheitis with a recombinant fowlpox virus co-expressing the $F$, $\mathrm{HN}$ genes of Newcastle disease virus and $\mathrm{gB}$ gene of infectious laryngotracheitis virus. Avian Dis 2008, 52:111-7.

139. Davison S, Gingerich EN, Casavant S, Eckroade RJ: Evaluation of the efficacy of a live fowlpox-vectored infectious laryngotracheitis/avian encephalomyelitis vaccine against ILT viral challenge. Avian Dis 2006, 50:50-4.

140. Zhang GZ, Zhang R, Zhao HL, Wang XT, Zhang SP, Li XJ, Qin CZ, Lv CM, Zhao JX, Zhou JF: A safety assessment of a fowlpox-vectored Mycoplasma gallisepticum vaccine in chickens. Poult Sci 2010, 89:1301-6.

141. Rerks-Ngarm S, Pitisuttithum P, Nitayaphan S, Kaewkungwal J, Chiu J, Paris R, Premsri N, Namwat $C$, de Souza M, Adams E, Benenson M,
Gurunathan S, Tartaglia J, McNeil JG, Francis DP, Stablein D, Birx DL, Chunsuttiwat S, Khamboonruang C, Thongcharoen P, Robb ML, Michael NL, Kunasol P, Kim JH, MOPH-TAVEG Investigators: Vaccination with ALVAC and AIDSVAX to prevent HIV-1 infection in Thailand. N Engl J Med 2009, 361:2209-20.

142. Pialoux G, Gahéry-Ségard H, Sermet S, Poncelet H, Fournier S, Gérard L, Tartar A, Gras-Masse H, Levy JP, Guillet JG, ANRS VAC 04 Study Team: Lipopeptides induce cell-mediated anti-HIV immune responses in seronegative volunteers. AIDS 2001, 15:1239-49.

143. Kaufman HL, Lenz HJ, Marshall J, Singh D, Garett C, Cripps C, Moore M, von Mehren M, Dalfen R, Heim WJ, Conry RM, Urba WJ, Benson AB, Yu M, Caterini J, Kim-Schulze S, Debenedette M, Salha D, Vogel T, Elias I, Berinstein NL: Combination chemotherapy and ALVAC-CEA/B7.1 vaccine in patients with metastatic colorectal cancer. Clin Cancer Res 2008, 14:4843-9.

144. Imoukhuede EB, Berthoud T, Milligan P, Bojang K, Ismaili J, Keating S, Nwakanma D, Keita S, Njie F, Sowe M, Todryk S, Laidlaw SM, Skinner MA, Lang T, Gilbert S, Greenwood BM, Hill AV: Safety and immunogenicity of the malaria candidate vaccines FP9 CS and MVA CS in adult Gambian men. Vaccine 2006, 24:6526-33.

doi:10.1186/1743-422X-8-49

Cite this article as: Weli and Tryland: Avipoxviruses: infection biology and their use as vaccine vectors. Virology Journal 2011 8:49.

\section{Submit your next manuscript to BioMed Central and take full advantage of:}

- Convenient online submission

- Thorough peer review

- No space constraints or color figure charges

- Immediate publication on acceptance

- Inclusion in PubMed, CAS, Scopus and Google Scholar

- Research which is freely available for redistribution

Submit your manuscript at www.biomedcentral.com/submit
Ciomed Central 